\title{
Evaluation of In vivo Antitrypanosomal Activity of Aqueous and Methanol Leaf Extracts of Clutia abyssinica (Euphorbiaceae) against Trypanosoma congolense Field Isolate
}

Ermias Mergia', Workineh Shibeshi' ${ }^{2}$, Getachew Terefe $^{3}$ and Tilahun Teklehaymanot ${ }^{4}$

${ }^{1}$ Department of Pharmacy, Faculty of Health Sciences, Rift Valley University College, Ethiopia

${ }^{2}$ Department of Pharmacology and Clinical Pharmacy, Faculty of Health Sciences, Addis Ababa University, Ethiopia

${ }^{3}$ Department of Parasitology, Faculty of Veterinary Medicine, Addis Ababa University, Ethiopia

${ }^{4}$ Endod and Other Medicinal Plants Unit, Aklilu Lemma Institute of Pathobiology, Addis Ababa University, Ethiopia

\begin{abstract}
Aqueous and methanol leaf extracts of $C$. abyssinica were investigated for their in vivo activity against Trypanosoma congolence, the main causative agent of African animal trypanosomosis in Sub-Saharan Africa and Ethiopia. The in vivo antitrypanosomal efficacy of the aqueous and methanol extracts was evaluated in Swiss albino mice infected with $T$. congolense field isolate. The leaf extracts were administered 12 days post-infection at peak parasitaemia level of $\sim 10^{8}$ trypanosomes $/ \mathrm{ml}$ at doses of 100,200 and $400 \mathrm{mg} / \mathrm{kg}$ by intraperitoneal injection once daily for 7 days. Parasitaemia, packed cell volume (PCV), mean survival time and change in body weight were used as indices for monitoring the efficacy of the extracts by comparing with the positive control: $28 \mathrm{mg} / \mathrm{kg}$ dose of diminazene aceturate and negative control: $2 \%$ tween 80 treated groups. The extracts had a lethal dose greater than $2000 \mathrm{mg} / \mathrm{kg}$ and there were no evidences of acute toxicity at the doses tested. Highly significant $(p<0.001)$ reduction in pre-treatment parasitaemia by $3.91 \%(7.38 \pm 0.18)$, increase in PCV by $1.12 \%(48.66 \pm 0.20)$, body weight improvement by $1.36 \%$ $(22.34 \pm 0.27)$ and mean survival time of $39.20 \pm 0.37$ days was observed in the group treated by $400 \mathrm{mg} / \mathrm{kg}$ methanol leaf extract of $C$. abyssinica. In general, the results obtained suggest ethno-pharmacological usefulness of the plant and necessitate further studies to be carried on isolated active substances from the plant.
\end{abstract}

Keywords: Trypanosomosis; Trypanosoma congolense; Clutia abyssinica; Parasitaemia; Packed cell volume; Body weight; Mean survival time

\section{Introduction}

African trypanosomosis is a protozoan disease of man and livestock. It is caused by trypanosomes and transmitted by tse tse fly. While Trypanosoma rhodiense and Trypanosoma gambiense cause African Human Trypanosomosis (AHT, sleeping sickness), Trypanosoma brucei brucei, Trypanosoma vivax, Trypanosoma congolense, Trypanosoma evansi and Trypanosoma equiperdum are the agents of African Animal Trypanosomosis (AAT) [1]. The economic impacts of trypanosomosis in Africa are diverse and complex, with direct effects on animal production and human health, as well as indirect effects on settlement patterns, land use, animal husbandry and farming [2]. AAT is associated with fever, depression, weakness, anemia, salivation, lacrimation, nasal discharges, and subcutaneous edema of the mandible and prominent jugular pulse. The appetite is decreased and there is a rapid weight loss which progresses to an extreme emaciation. Often, death is related to severe anemia and circulatory collapse [3].

Chemotherapy, the main means of controlling the disease is under threat due to parasite resistance [4] and toxicity of the trypanocidal drugs [5]. The poor prospect for a vaccine due to antigenic variation of the parasite is further compounded by unwillingness of the pharmaceutical industry to develop new compounds because of uncertain and unprofitable market or perhaps the localized nature of the disease. The few commercial trypanocides (diminazene aceturate, isometamidium and homidium) have been in use for well over 40 years. Thus, the search for medicinal plants with trypanocidal activities continues to generate a lot of research interest [6,7]. Although recent reports indicate antitrypanosomal activity exists in some medicinal plants [8-10], the potentials of many other plants used in folkloric medicine in Ethiopia are yet to be investigated. This study was designed to determine the in vivo antitrypanosomal activity of Clutia abyssinica against $T$. congolense infected mice.

\section{Clutia abyssinica (Fam. Euphorbiaceae)}

Euphorbiaceae is a large and fascinating family of about 300 genera and 8,000-10,000 species, mostly found in the tropics of both hemispheres. Clutia is a genus having about 60 species. Clutia abyssinica called by the Amharic name 'fyele fej' is herb 1-2 m high [11]. Traditionally it is used in treatment of venereal and skin diseases, chest problems, cancer [12] ; Skin fungal infections [13,14]; Yellow fever and malaria [15]; management of ear, nose and throat diseases [16]; diarrhoea [17] ; gonorrhea, cough and fever, headache, toothache, menstrual pain, burns, pneumonia, enlarged spleen and kidney, shock, abdominal problems- as a laxative and to expel intestinal worms, elephantiasis, diarrhoea and tachycardia [14]. Moreover, maceration of the crushed leaves of C. abyssinica given orally has traditionally been used for the treatment of animal trypanosomosis [18].

\section{Material and Methods}

\section{Reference Drug}

Diminazine aceturate (Veriben ${ }^{\circledR}$ containing 1.05 gm diminazene aceturate +2.36 gm antipyrine, (Ceva Santé Animale, France; batch number- 719A1) a commercial trypanocidal drug was used.

*Corresponding author: Ermias Mergia, Department of Pharmacy, Faculty of Health Sciences, Rift Valley University College, Ethiopia, Tel: +251911362367; E-mail: mergiae@gmail.com

Received May 02, 2014; Accepted May 20, 2014; Published May 22, 2014

Citation: Mergia E, Shibeshi W, Terefe G, Teklehaymanot T (2014) Evaluation of In vivo Antitrypanosomal Activity of Aqueous and Methanol Leaf Extracts of Clutia abyssinica (Euphorbiaceae) against Trypanosoma congolense Field Isolate. Nat Prod Chem Res 2 :138. doi:10.4172/2329-6836.1000138

Copyright: $\odot 2014$ Mergia E, et al. This is an open-access article distributed under the terms of the Creative Commons Attribution License, which permits unrestricted use, distribution, and reproduction in any medium, provided the original author and source are credited. 
Citation: Mergia E, Shibeshi W, Terefe G, Teklehaymanot T (2014) Evaluation of In vivo Antitrypanosomal Activity of Aqueous and Methanol Leaf Extracts of Clutia abyssinica (Euphorbiaceae) against Trypanosoma congolense Field Isolate. Nat Prod Chem Res $2: 138$. doi:10.4172/23296836.1000138

Page 2 of 8

\section{Test organism}

The test organism, T. congolense was isolated from infected cattles at Sebategna kebele of Ilu-Aba-Bora-Zone, $480 \mathrm{~km}$ from Addis Ababa in South west direction. Blood samples were collected from the peripheral ear vein of each animal using heparinized microhaematocrit capillary tubes that filled $3 / 4$ of the height and sealed with cristaseal. The presence of $T$. congolense was detected by Microhaematocrit Buffy Coat Technique (MHBCT) [19] where the sealed microhaematocrit capillary tubes were centrifuged immediately in microhaematocrit centrifuge for $5 \mathrm{~min}$ at $12000 \mathrm{rpm}$. After centrifugation, the capillary tube was cut by diamond pencil $1 \mathrm{~mm}$ below the buffy coat to include the top layer of red cells. The content of the capillary tube was expressed onto a clean microscope slide, mixed and covered with a $22 \times 22 \mathrm{~mm}$ cover slip.

Then the slide was examined for $T$. congolense based on their type of motility in the microscopic field 400X objective. Confirmations of $T$. congolense species by morphological characteristics was done after a thin blood smear was prepared from the buffy-coat examination and stained with Giemsa stain and examined under a microscope using oil immersion 100X objective [20,21]. Then an animal with peak parasiaemia of $\left(\sim 10^{8}\right.$ trypanosomes $\left./ \mathrm{ml}\right)$ [22] was selected and blood was collected to the ethylene diamine tetra acetic acid (EDTA) coated tube from the jugular vein of the animal and diluted with PBS.

Then $0.2 \mathrm{ml}$ of the blood containing $\sim 10^{4}$ trypanosomes $/ \mathrm{ml}$ was injected intraperitoneally to 6 laboratory mice and transported to the laboratory at Akililu Lemma Institute of Pathobiology (ALIPB), Addis Ababa University for serial passage to other mice for the experimental part of the study. The development of trypanosomes in the infected mice was determined by wet film examination of blood obtained from the tail of the mice by buffy coat method [19]. Following syringe challenge all the donor mice had shown parasitaemia 7 days postinfection. After establishment of infection heavily $\left(\sim 10^{8}\right.$ trypanosomes/ $\mathrm{ml}$ ) (21 days post- inoculation), the donor mice were then subjected to cardiac puncture and blood was collected with an EDTA coated tube and immediately diluted with phosphate buffered saline. Then about $0.2 \mathrm{ml}$ of blood collected from the donor mice containing $\left(\sim 10^{4}\right.$ trypanosomes $/ \mathrm{ml}$ ) [22] was injected intraperitoneally in to mice that were acclimatized to laboratory conditions and were used for in vivo evaluation of the crude leaf extracts of C. abyssinica.

\section{Experimental animals}

Healthy Swiss albino mice (weighing 20-30 gm and age of 8-12 weeks) were obtained from the animal house of the Ethiopian Health and Nutrition Research Institute (EHNRI) and School of Pharmacy, Addis Ababa University. Animals were housed in polypropylene cages (6-10 animals per cage), maintained less than $12 \mathrm{hr}$ light and $12 \mathrm{hr}$ dark cycle and allowed free access to pellet diet and clean water ad libitum. All procedures complied with the guide for the care and use of laboratory animals [23].

\section{Collection of plant specimens}

The leaves of C. abyssinica were collected in the month of April 2013 from Debre Libanos 'gedam', a Monastery in Amhara regional state, Ethiopia. The fresh leaves were wrapped by plastic sheets during transportation. Taxonomic identification was done and a voucher specimen was deposited (Collection EM/001) at the National Herbarium, College of Natural sciences, Addis Ababa University. The leaves were thoroughly washed with distilled water to remove dirt, soil and any other foreign materials and left to drain off. Then they were then spread on laboratory bench and dried under shade. The dried leaves were pulverized using mortar and pestle at medicinal plants laboratory of ALIPB.

\section{Preparation and storage of extracts}

$200 \mathrm{~g}$ of dried leaf powder of C. abyssinica was separately macerated with $1000 \mathrm{ml}$ of distilled water and methanol for 48 hours with frequent agitation in orbital shaker and the resulting liquid was filtered using Whattman No. 3 filter paper (Whattman Ltd., England). Extraction was repeated three times and the filtrates of all portions were pooled in one vessel. The aqueous extract was placed in a Petridish and lyophilized for one week to yield a solid residue, while the methanol extract was concentrated using Rota vapor (BÜCHI Rota-vapor, Switzerland) at not more than $40^{\circ} \mathrm{C}$ in order to obtain dry extract. Then the resulting dried mass was then powdered, weighed and packed into a glass vial and stored in a desiccator over silica gel until use.

\section{Phytochemical screening}

Aqueous and methanol extracts of C. abyssinica were screened for the presence of active principles such as alkaloids, anthraquinones, flavonoids, glycosides, phenolic compounds, saponins, steroids, tannins and terpenes using standard methods [24-29].

\section{Acute toxicity study}

The acute toxicity study was conducted in accordance with the Lorke's method [30]. The study was conducted for each extract in two phases using female swiss albino mice after 7 days of adaptation. In the first phase, nine mice were divided into 3 groups of 3 mice each. Each group was given 10, 100, and $1000 \mathrm{mg} / \mathrm{kg}$ body weight of the test substance respectively. In the second phase, further specific doses $(1600,2900$, and $5000 \mathrm{mg} / \mathrm{kg})$ of each extract were administered to nine mice (three mice per dose) to further determine the correct lethal dose $\left(\mathrm{LD}_{50}\right)$ value. In addition, a fourth group of six mice was set up as control group and received the reconstituting solvent $2 \%$ tween 80 in sterile water.

Each extract was dissolved in $2 \%$ tween 80 in sterile water and given through intraperitoneal route. All animals were kept under strict observation for behavioral, neurological, autonomic or physical changes such as alertness, motor activity, restlessness, convulsions, coma, diarrhea and lacrimation for $24 \mathrm{~h}$, with special attention during the first $4 \mathrm{~h}$. These observations continued for further 14 days for any signs of overt toxicity. Then the lowest dose which killed one mouse (minimum toxic dose) and the highest dose which had not killed any mouse (maximum tolerated dose) were noted, and the geometric mean of these two doses gave $\mathrm{LD}_{50}$.

\section{Parasite inoculation and extract administration}

40 healthy Swiss albino mice that are infected intraperitoneally with $0.2 \mathrm{ml}$ of $T$. congolense infected blood $\left(\sim 10^{4}\right.$ trypanosomes $\left./ \mathrm{ml}\right)$ collected by cardiac puncture from donor mice was divided into eight groups: C. abyssinica aqueous extract (CAAE 100, CAAE 200, CAAE 400), C. abyssinica methanol extract (CAME 100, CAME 200, CAME 400), Diminazine aceturate (DA28), and 2\% tween 80 (TW80) each comprising of 5 mice.

Treatment with the extracts began on the $12^{\text {th }}$ day post-infection (day 0 of treatment), when the infected mice show peak parasitaemia of $\left(\sim 10^{8}\right.$ trypanosomes $\left./ \mathrm{ml}\right)$. On each day of drug administration, the aqueous and methanol extracts of $C$. abyssinica were freshly prepared by solublising in $2 \%$ Tween- 80 in sterile water for injection and administered intraperitoneally daily at 9 a.m for seven days at the doses of $(100,200$ and $400 \mathrm{mg} / \mathrm{kg})$. The doses were selected based on the acute 
Citation: Mergia E, Shibeshi W, Terefe G, Teklehaymanot T (2014) Evaluation of In vivo Antitrypanosomal Activity of Aqueous and Methanol Leaf Extracts of Clutia abyssinica (Euphorbiaceae) against Trypanosoma congolense Field Isolate. Nat Prod Chem Res $2: 138$. doi:10.4172/23296836.1000138

Page 3 of 8

toxicity study. The middle dose was one tenth of the lethal dose ( 2000 $\mathrm{mg} / \mathrm{kg}$ ) which was $200 \mathrm{mg} / \mathrm{kg}$. Higher dose was calculated as twice the middle dose, which was $400 \mathrm{mg} / \mathrm{kg}$. The lower dose level was calculated by taking half of the middle dose, which was $100 \mathrm{mg} / \mathrm{kg}$. For the positive control, diminazine aceturate $\left(\right.$ Veriben $\left.^{\circledR}\right)$ (DA28), dissolved in sterile water as recommended by the manufacturer (Ceva Santé Animale, France) was administered at the dose of $28 \mathrm{mg} / \mathrm{kg}$ intraperitoneally based on previous reports, while for the negative control, $2 \%$ tween 80 in sterile water (TW80), was administered intraperitoneally. Volume administered was determined based on the organization of Economic Co-operation and Development (OECD) guideline that states $2 \mathrm{ml} / 100$ gm of body weight of the animal.

\section{Determination of parasitaemia}

Parasitaemia was monitored every other day by microscopic examination of blood obtained from the tail of each mouse that was pre-sterilized with methylated spirit. The tail tip was cut to extrude blood and drop of blood was placed on microscope slide and covering with a cover-slide $(22 \times 22 \mathrm{~mm})$ (OIE, 2013) [31]. The blood was examined microscopically at $400 \mathrm{X}$ total magnification. The degree of parasitaemia was determined using the "Rapid Matching" method of [22]. Wet smear were prepared in triplicates from each animal and the mean value of slide counts were taken per sample examined microscopically. Logarithm values of these counts were obtained by matching with the table given by [22].

\section{Determination of packed cell volume (PCV)}

PCV was measured using Wintrobe's method [32] to predict the effectiveness of the test extracts in preventing hemolysis resulting from increasing parasitaemia associated with trypanosomosis. It was monitored before infection and three times till the $14^{\text {th }}$ day (on day 0,7 14). Briefly, blood was collected from tail of each mouse in heparinized microhaematocrit capillary tubes filled up to $3 / 4^{\text {th }}$ of their length. The tubes were then sealed immediately by cristalseal and centrifuged in a microhaematocrit centrifuge (Hettich Haematokrit, Germany) for 5 min at 12,000 rpm. After centrifugation, the height of the red blood cell column were measured by use of haematocrit reader and compared to the total height of the column of the whole blood (Wernery et al., 2001) [33]. The effect of extracts in improving PCV of treated animals was compared with the controls.

\section{Determination of body weight}

The body weight of each mouse in all groups was measured before infection, on the day treatment commenced (day 0 ) and every other day up to day 14 .

\section{Determination of mean survival time}

Mortality was monitored daily and the number of days from the time of inoculation of the parasite up to death was recorded for each mouse in the treatment and control groups throughout the follow up period for six weeks.

Statistical analysis: Values of the data obtained from the study were summarized and expressed as mean \pm standard error of mean (SEM). Data analysis was performed using Statistical Package for Social Science (SPSS), version 17.0. To compare the results obtained from different groups, one way ANOVA followed by Tukey's multiple comparison tests were performed to determine statistical significance. $P$ values less than 0.05 were considered significant.

\section{Results}

\section{Yield for plant extraction}

The yield of aqueous and methanol leaf extracts of Clutia abyssinica (Table 1)

\section{Phytochemical screening}

The results of phytochemical screening results for the aqueous and methanol leaf extracts of Clutia abyssinica is shown in (Table 2)

\section{Acute toxicity test}

The acute toxicity bioassay had shown that the lethal dosage $\left(\mathrm{LD}_{50}\right)$ of the aqueous and methanol leaf extracts of C. abyssinica was above $2000 \mathrm{mg} / \mathrm{kg}$ and there were no evidences of acute toxicity at the doses tested indicating good safety margin.

\section{Effect on Parasitaemia}

Mice treated with aqueous extract of C. abyssinica at $400 \mathrm{mg} / \mathrm{kg}$ dose had low parasitaemia on day $6(\mathrm{p}<0.01)$, day 8,10 and $14(\mathrm{p}<0.001)$ (Table 3), while animals treated with the methanol extract at 200 and $400 \mathrm{mg} / \mathrm{kg}$ dose had statistically significant low parasitaemia on day 6 , 8,10 and $14(\mathrm{p}<0.001)$ of treatment as compared to the negative control group (Table 4$)$.

\section{Effect on packed cell volume (PCV)}

The mean PCV\% value of animals treated with $400 \mathrm{mg} / \mathrm{kg}$ of the aqueous extract of C. abyssinica, with 200 and $400 \mathrm{mg} / \mathrm{kg}$ dose of the methanol extract had a statistically significant $(\mathrm{p}<0.001)$ higher PCV value as compared to the negative control groups on day 14 of treatment (Table 5). Analysis of change in percentage of PCV from day 7 to day 14 of treatment also showed that the methanol extracts at 200 and $400 \mathrm{mg} / \mathrm{kg}$ doses had significantly increased PCV value of treated animals by 1.29 and $1.12 \%$, respectively as compared to the negative control groups which had a drop in PCV by $9.38 \%$ from day 7 to 14 of treatment (Table 6). This finding was consistent with the effect shown by the extracts on parasitaemia level of $T$. congolense infected mice (Figures 1 and 2).

\begin{tabular}{|l|c|c|c|}
\hline Plant species & Part extracted & Solvent & Percentage yield (\%w/w) \\
\hline C. abyssinica & Leaf & Distilled water & $12.92 \%$ \\
\hline & & Methanol & $17.21 \%$ \\
\hline
\end{tabular}

Table 1: Percentage yields of aqueous and methanol leaf extracts of Clutia abyssinica.

\begin{tabular}{|l|c|c|}
\hline \multirow{2}{*}{ Constituents } & \multicolumn{2}{|c|}{ C. abyssinica } \\
\cline { 2 - 3 } & Aqueous extract & Methanol extract \\
\hline Alkaloids & - & + \\
\hline Anthraquinones & + & + \\
\hline Flavonoids & - & + \\
\hline Glycoside & - & + \\
\hline Saponins & + & + \\
\hline Steroids & - & + \\
\hline Phenolic compounds & + & + \\
\hline Tannins & - & + \\
\hline Terpenes & - & + \\
\hline
\end{tabular}

+ =present, - =absent

Table 2: Phytochemical screening results for the aqueous and methanol leaf extracts of Clutia abyssinica. 
Citation: Mergia E, Shibeshi W, Terefe G, Teklehaymanot T (2014) Evaluation of In vivo Antitrypanosomal Activity of Aqueous and Methanol Leaf Extracts of Clutia abyssinica (Euphorbiaceae) against Trypanosoma congolense Field Isolate. Nat Prod Chem Res $2: 138$. doi:10.4172/23296836.1000138

Page 4 of 8

\begin{tabular}{|c|c|c|c|c|c|}
\hline \multirow{2}{*}{ Days } & \multicolumn{5}{|c|}{ Parasitaemia (log number/ml) } \\
\hline & DA28 & TW80 & CAAE100 & CAAE200 & CAAE400 \\
\hline Day 0 & $7.68 \pm 0.18$ & $7.44 \pm 0.17$ & $7.38 \pm 0.07$ & $7.68 \pm 0.18$ & $7.33 \pm 0.14$ \\
\hline Day 2 & $0.00 \pm 0.00^{* 3}$ & $7.74 \pm 0.17$ & $7.62 \pm 0.07$ & $7.92 \pm 0.15$ & $7.56 \pm 0.11$ \\
\hline Day 4 & $0.00 \pm 0.00^{* 3}$ & $7.86 \pm 0.11$ & $7.86 \pm 0.11$ & $7.98 \pm 0.07$ & $7.68 \pm 0.18$ \\
\hline Day 6 & $0.00 \pm 0.00^{* 3}$ & $8.16 \pm 0.11$ & $7.68 \pm 0.12$ & $7.80 \pm 0.13$ & $7.44 \pm 0.19^{\mathrm{b} 2}$ \\
\hline Day 8 & $0.00 \pm 0.00^{* 3}$ & $8.28 \pm 0.07^{* 3}$ & $7.44 \pm 0.11^{\mathrm{b} 3}$ & $7.62 \pm 0.07^{\mathrm{b} 3}$ & $6.96 \pm 0.17^{\mathrm{b3}, \mathrm{c} 1 \mathrm{~d}, \mathrm{~d} 2}$ \\
\hline Day 10 & $0.00 \pm 0.00^{* 3}$ & $8.52 \pm 0.12^{* 3}$ & $7.80 \pm 0.13^{\mathrm{b3}}$ & $7.86 \pm 0.06^{\mathrm{b} 3}$ & $7.26 \pm 0.14^{\mathrm{b} 3, \mathrm{c} 1, \mathrm{~d} 2}$ \\
\hline Day 12 & $2.16 \pm 1.32^{\star 3}$ & $8.64 \pm 0.06$ & $8.22 \pm 0.07$ & $8.04+0.06$ & $7.74+0.11$ \\
\hline Day 14 & $5.52 \pm 0.07^{* 3}$ & $8.82 \pm 0.12$ & $8.52 \pm 0.07$ & $8.28 \pm 0.07$ & $8.04 \pm 0.06^{63,12}$ \\
\hline \% Change in Parasitaemia (Day 0-14) & -27.3 & 18.55 & 15.45 & 7.81 & 9.68 \\
\hline
\end{tabular}

Values are expressed in Mean \pm S.E.M ( $n=5)$ performed with ANOVA followed by Tukey's Post hoc multiple comparison test; DA28=diminazine aceturate 28 mg/kg-the positive control, ${ }^{b} \mathrm{Compared}$ to TW80 $=2 \%$ tween 80 -the negative control; ${ }^{\circ} \mathrm{Compared}$ to CAAE $100=\mathrm{C}$. abyssinica aqueous extract $100 \mathrm{mg} / \mathrm{kg}$, ${ }^{\mathrm{d}} \mathrm{Compared} \mathrm{to} \mathrm{CAAE} 200=\mathrm{C}$. abyssinica aqueous extract $200 \mathrm{mg} / \mathrm{kg}$, ecompared to CAAE400=C. abyssinica aqueous extract $400 \mathrm{mg} / \mathrm{kg}$, ${ }^{*} \mathrm{Compared} \mathrm{with} \mathrm{all} \mathrm{groups;}{ }^{1} \mathrm{p}<0.05,{ }^{2} \mathrm{p}<0.01$ and ${ }^{3} \mathrm{p}<0.001$

Table 3: The effect of aqueous leaf extract of Clutia abyssinica on parasitaemia level of Trypanosoma congolense infected mice.

\begin{tabular}{|c|c|c|c|c|c|}
\hline \multirow{2}{*}{ Days } & \multicolumn{5}{|c|}{ Parasitaemia (log number/ml) } \\
\cline { 2 - 6 } & DA28 & TW80 & CAAE100 & CAAE200 & CAAE400 \\
\hline Day0 & $7.68 \pm 0.18$ & $7.44 \pm 0.17$ & $7.56 \pm 0.15$ & $7.32 \pm 0.12$ & $7.68 \pm 0.18$ \\
\hline Day2 & $0.00 \pm 0.00^{* 3}$ & $7.74 \pm 0.17$ & $7.68 \pm 0.18$ & $7.50 \pm 0.13$ & $7.62 \pm 0.20$ \\
\hline Day4 & $0.00 \pm 0.00^{* 3}$ & $7.86 \pm 0.11$ & $7.92 \pm 0.24$ & $7.38 \pm 0.07$ & $7.32 \pm 0.22$ \\
\hline Day6 & $0.00 \pm 0.00^{* 3}$ & $8.16 \pm 0.11$ & $7.68 \pm 0.18$ & $7.26 \pm 0.22^{\mathrm{b3}}$ & $6.54 \pm 0.11^{\mathrm{bc} 3, \mathrm{~d} 1}$ \\
\hline Day8 & $0.00 \pm 0.00^{* 3}$ & $8.28 \pm 0.07$ & $7.92 \pm 0.18$ & $6.78 \pm 0.07^{\mathrm{bc} 3}$ & $5.94 \pm 0.24^{* 3}$ \\
\hline Day10 & $0.00 \pm 0.00^{* 3}$ & $8.52 \pm 0.12$ & $8.16 \pm 0.17$ & $7.32 \pm 0.15^{\mathrm{b} 3, \mathrm{c} 2}$ & $6.24 \pm 0.22^{* 3}$ \\
\hline Day12 & $2.16 \pm 1.32^{* 3}$ & $8.64 \pm 0.06$ & $8.28 \pm 0.15$ & $7.74 \pm 0.17$ & $7.26 \pm 0.11$ \\
\hline Day14 & $5.52 \pm 0.07^{* 3}$ & $8.82 \pm 0.12$ & $8.52 \pm 0.15$ & $7.92 \pm 0.15^{\mathrm{b} 3, \mathrm{cc}}$ & $7.38 \pm 0.18^{\mathrm{bc} 3}$ \\
\hline \% Change in Parasitaemia (Day 0-14) & -27.3 & 18.55 & 12.69 & 8.19 & -3.91 \\
\hline
\end{tabular}

Values are expressed in Mean \pm S.E.M $(n=5)$ performed with ANOVA followed by Tukey's Post hoc multiple comparison test; DA28=diminazine aceturate $28 \mathrm{mg} / \mathrm{kg}$ the positive control, ${ }^{b} \mathrm{Compared}$ to TW $80=2 \%$ tween 80 -the negative control; ${ }^{\circ} \mathrm{Compared}$ to CAME $100=C$. abyssinica methanol extract $100 \mathrm{mg} / \mathrm{kg}$, ${ }^{\mathrm{d}} \mathrm{Compared}$ to CAME200 $=C$. abyssinica methanol extract $200 \mathrm{mg} / \mathrm{kg}$, ${ }^{e}$ Compared to CAME400 $=C$. abyssinica methanol extract $400 \mathrm{mg} / \mathrm{kg},{ }^{*} \mathrm{Compared}$ with all groups; ${ }^{1} \mathrm{p}<0.05,{ }^{2} \mathrm{p}<0.01$ and ${ }^{3} \mathrm{p}<0.001$

Table 4: The effect of methanol leaf extract of Clutia abyssinica on parasitaemia of Trypanosoma congolense infected mice.

\begin{tabular}{|c|c|c|c|c|c|}
\hline \multirow{2}{*}{ Days } & \multicolumn{5}{|c|}{ PCV\% Values } \\
\hline & DA28 & TW80 & CAAE100 & CAAE200 & CAAE400 \\
\hline Pre-infection & $51.18 \pm 0.37$ & $50.88 \pm 0.14$ & $51.40 \pm 0.22$ & $51.02 \pm 0.22$ & $50.66 \pm 0.23$ \\
\hline Day 0 & $49.40 \pm 0.23$ & $49.04 \pm 0.29$ & $49.24 \pm 0.28$ & $49.10 \pm 0.24$ & $49.16 \pm 0.24$ \\
\hline Day 7 & $48.88 \pm 0.25^{\star 3}$ & $44.78 \pm 0.37$ & $44.04 \pm 0.12$ & $45.34 \pm 0.42^{\mathrm{c} 1}$ & $45.48 \pm 0.28^{\mathrm{c} 1}$ \\
\hline$\%$ Change PCV day 7-0 & -1.05 & -8.69 & -10.56 & -7.65 & -7.48 \\
\hline Day 14 & $50.08 \pm 0.15^{* 3}$ & $40.58 \pm 0.27^{* 3}$ & $43.36 \pm 0.24^{\mathrm{b} 3}$ & $44.70 \pm 0.28^{\mathrm{b} 3, \mathrm{c} 1}$ & $45.04+0.31^{\mathrm{b} 3, \mathrm{c} 2}$ \\
\hline \% Change PCVday 7-14 & 2.45 & -9.38 & -1.54 & -1.41 & -0.96 \\
\hline
\end{tabular}

Values are expressed in Mean \pm S.E.M ( $n=5)$ performed with ANOVA followed by Tukey's Post hoc multiple comparison test; DA28=diminazine aceturate 28 mg/kg-the positive control, CAAE200 $=C$. abyssinica aqueous extract $200 \mathrm{mg} / \mathrm{kg}$, CAAE400=C. abyssinica aqueous extract $400 \mathrm{mg} / \mathrm{kg}$; ${ }^{\mathrm{b}} \mathrm{compared}$ to $\mathrm{TW} 80=2 \%$ tween 80 -the negative control, ${ }^{\mathrm{C}} \mathrm{Compared}$ to $\mathrm{CAAE} 100=C$. abyssinica aqueous extract $100 \mathrm{mg} / \mathrm{kg}$, ${ }^{*}$ compared with all groups; ${ }^{1} \mathrm{p}<0.05,{ }^{2} \mathrm{p}<0.01$ and ${ }^{3} \mathrm{p}<0.001$

Table 5: The effect of the aqueous leaf extract of Clutia abyssinica on packed cell volume of Trypanosoma congolense infected mice.

\begin{tabular}{|c|c|c|c|c|c|}
\hline \multirow{2}{*}{ Days } & \multicolumn{5}{|c|}{ PCV\% Values } \\
\hline & DA28 & TW80 & CAAE100 & CAAE200 & CAAE400 \\
\hline Pre-infection & $51.18 \pm 0.37$ & $50.88 \pm 0.14$ & $51.10 \pm 0.26$ & $51.24 \pm 0.20$ & $51.56 \pm 0.08$ \\
\hline Day 0 & $49.40 \pm 0.23$ & $49.04 \pm 0.29$ & $49.16 \pm 0.24$ & $49.08 \pm 0.29$ & $49.04 \pm 0.23$ \\
\hline Day 7 & $48.88 \pm 0.25^{\star 3}$ & $44.78 \pm 0.37$ & $46.06 \pm 0.22^{\mathrm{b} 1}$ & $46.22 \pm 0.32^{\mathrm{b} 2}$ & $48.12 \pm 0.15^{\mathrm{bcd} 3}$ \\
\hline$\%$ change PCV day $7-0$ & -1.05 & -8.69 & -6.30 & -5.82 & -1.87 \\
\hline Day 14 & $50.08 \pm 0.15^{\star 3}$ & $40.58 \pm 0.27^{* 3}$ & $45.66 \pm 0.22^{\mathrm{b} 3}$ & $46.82 \pm 0.34^{\mathrm{b} 3}$ & $48.66 \pm 0.20^{\mathrm{b} 3, \mathrm{c} 1, \mathrm{~d} 2}$ \\
\hline \%change PCV day 7-14 & 2.45 & -9.38 & -0.86 & 1.29 & 1.12 \\
\hline
\end{tabular}

Values are expressed in Mean \pm S.E.M ( $n=5)$ performed with ANOVA followed by Tukey's Post hoc multiple comparison test; DA28=diminazine aceturate 28 mg/kg-the positive control, CAME400 $=C$. abyssinica methanol extract $400 \mathrm{mg} / \mathrm{kg}$; ${ }^{\mathrm{b}} \mathrm{compared}$ to $\mathrm{TW} 80=2 \%$ tween 80 -the negative control, ${ }^{\mathrm{c}} \mathrm{Compared}$ to $\mathrm{CAME} 100=C$. abyssinica methanol extract $100 \mathrm{mg} / \mathrm{kg}$, dcompared to CAME $200=C$. abyssinica methanol extract $200 \mathrm{mg} / \mathrm{kg} ;{ }^{*}$ compared with all groups; ${ }^{1} \mathrm{p}<0.05,{ }^{2} \mathrm{p}<0.01$ and ${ }^{3} \mathrm{p}<0.001$

Table 6: The effect of the methanol leaf extract of Clutia abyssinica on packed cell volume of Trypanosoma congolense infected mice.

\section{Effect on body weight}

Animals treated with $400 \mathrm{mg} / \mathrm{kg}$ dose of the aqueous extract of $C$. abyssinica had shown significant improvement on their body weight on day $6(\mathrm{p}<0.01), 8-14(\mathrm{p}<0.001)$ of treatment, while animals treated with 
Citation: Mergia E, Shibeshi W, Terefe G, Teklehaymanot T (2014) Evaluation of In vivo Antitrypanosomal Activity of Aqueous and Methanol Leaf Extracts of Clutia abyssinica (Euphorbiaceae) against Trypanosoma congolense Field Isolate. Nat Prod Chem Res 2 :138. doi:10.4172/23296836.1000138

Page 5 of 8

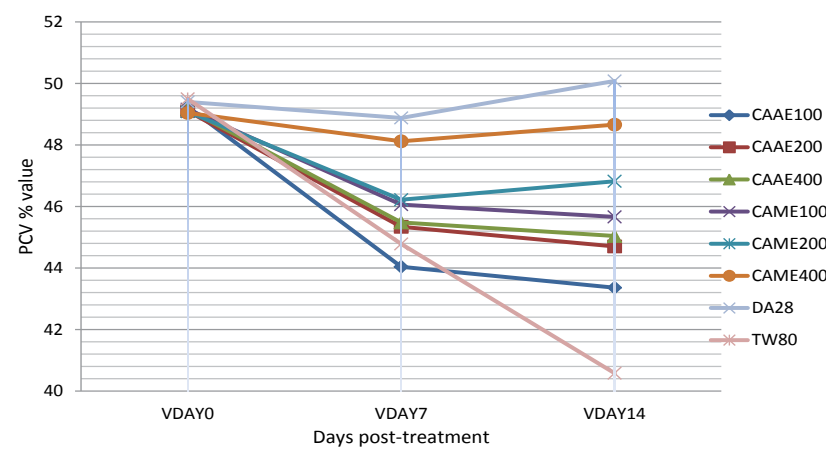

Figure 1: Comparison of the effect of aqueous and methanol leaf extracts of Clutia abyssinica on packed cell volume of Trypanosoma congolense infected mice.

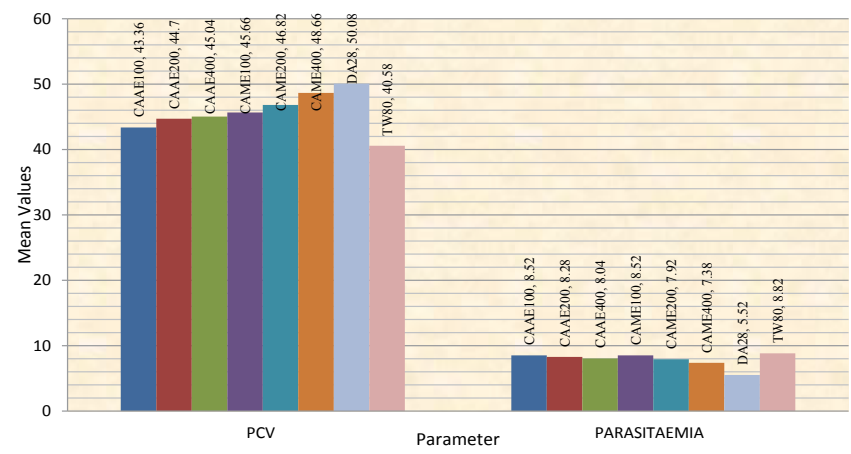

Figure 2: Comparison of the effect of aqueous and methanol leaf extracts of Clutia abyssinica on packed cell volume and parasitaemia.

the methanol extract at $400 \mathrm{mg} / \mathrm{kg}$ dose had improved body weight of treated animals $(\mathrm{P}<0.001)$ as compared to the negative control group and lower dose (100 and $200 \mathrm{mg} / \mathrm{kg}$ ) treated groups at $\mathrm{p}<0.05$. In addition animals treated with $400 \mathrm{mg} / \mathrm{kg}$ dose of the methanol extract had shown an improvement in their body weight by $1.36 \%$ (Figure 3 ).

\section{Effect on mean survival time}

Animals treated with $400 \mathrm{mg} / \mathrm{kg}$ of the methanol extract of $C$. abyssinica had highest mean survival time of $39.20 \pm 0.37$ days as compared to the negative control group $(25.40 \pm 0.43)$ (Table 7), while animals that received the positive control diminazine aceturate had mean survival time of $44.00 \pm 0.63$ days (Figure 4 ).

\section{Discussion}

Since the few trypanocides developed over 40 years ago are expensive and toxic [5], it has become necessary to search for new compounds that are safe and efficacious, especially those of plant origin. The plant screened in the present study has folkloric medicinal uses as fever remedies and treatment of infectious diseases including trypanosomosis $[17,18]$. Based on this, the aqueous extract was prepared by macerating the dried leaves in distilled water in order to simulate the way it is traditionally used $[17,18]$. With the assumption that some of the active ingredients responsible for the claimed antitrypanosomal activity might not be soluble in water adequately; the methanol leaf extract of the plant was also included in the study.

Based on the results of the acute toxicity study, the plant extracts had shown $\mathrm{LD}_{50}$ greater than $2000 \mathrm{mg} / \mathrm{kg}$. Thus, since C. abyssinica is believed to have several traditional medicinal uses by different traditional healers, the experimental determination of this good safety margin would justify that the plant is safe at the dose levels $(100,200$ and $400 \mathrm{mg} / \mathrm{kg}$ ) used in the study which is an additional proof for the medicinal value of the plant in folk medicine.

According to the results of the phytochemical screening study, the methanol extract of C. abyssinica showed positive test for the presence of alkaloids, flavonoids, glycosides, steroids, tannins and terpenes, while the aqueous extract showed a negative result for the same test.

Numerous in vivo studies conducted on the antitrypanosomal activities of the class of compounds listed above reported the potential of each class of compounds in killing or inhibiting the growth of wide ranges of trypanosomes.

Inhibition of the trypanosome alternative oxidase (TAO) enzyme was thought to be responsible for antitrypanosomal activity of phenolic compounds [34]. Quininos can induce oxidative stress in trypanosomes ( $T$. congolense and T. cruzi). This may be explained by their reduction to semiquinone radicals by enzymes such as those present in the mitochondrial electron transport chain and the trypanothione reductase [35]. Flavonoids and flavonoid-derived plant natural products have long been known to function as free radical scavengers and metal chelators: they inhibit lipid peroxidation and exhibit various physiological activities, including antihypertensive and anti-arthritic activities [6,36]. One of the molecular actions of tannins is by complexing proteins through the so-called nonspecific forces such as hydrogen bonding and hydrophobic effects, as well as by covalent bond formation [37]. The proposed mechanism for antitrypanosomal activity of terpenes include: by formation of aldehyde-thiol adducts with sulphur containing components thereby decreasing the buffering agents which can create oxidative stress in cells [38,39]; by oxidation of glutathione, pyruvic and alpha-ketoglutaric acids and the oxidative decarboxylation of pyruvic acid by hydroperoxy group which makes them toxic [40].

Therefore, the observed antitrypanosomal activity of C. abysinica might be attributed to either the individual class of compounds, or to the synergistic effect that each class of compounds exert to give the observed biological activity. Hence, further in-depth investigations should be carried out to resolve this issue $[41,42]$.

The results obtained during the monitoring period had shown that the higher dose $(400 \mathrm{mg} / \mathrm{kg})$ of the methanol extracts of C. abyssinica exhibited appreciable antitrypanosomal activity by reducing the level of parasitaemia by $3.91 \%$ as compared to the $18.55 \%$ increment in the negative control group and prolonging the lifespan of the test animals beyond that of the negative control by more than 10 days (Table 4).

This trypanostatic effect might correlate with the type of antiviral activity reported by Colegate and Molyneux $[43,44]$. In that report,

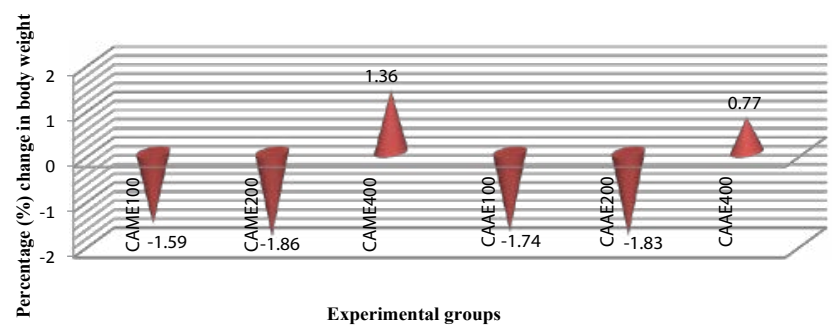

Figure 3: Comparison of the effect of aqueous and methanol leaf extracts of Clutia abyssinica on percentage change in body weight of Trypanosoma congolense infected mice 
Citation: Mergia E, Shibeshi W, Terefe G, Teklehaymanot T (2014) Evaluation of In vivo Antitrypanosomal Activity of Aqueous and Methanol Leaf Extracts of Clutia abyssinica (Euphorbiaceae) against Trypanosoma congolense Field Isolate. Nat Prod Chem Res $2: 138$. doi:10.4172/23296836.1000138

Page 6 of 8

\begin{tabular}{|c|c|c|c|c|c|c|}
\hline Plant & Extract & Dose $(\mathrm{mg} / \mathrm{kg})$ & Mean Parasitaemia & Mean PCV value & Mean Body weight & Mean survival time \\
\hline \multirow{6}{*}{ C. abyssinica } & \multirow{3}{*}{ Aqueous } & 100 & $8.52 \pm 0.07$ & $43.36 \pm 0.24$ & $21.25 \pm 0.20$ & $36.20 \pm 0.66$ \\
\hline & & 200 & $8.28 \pm 0.07$ & $44.70 \pm 0.28$ & $21.25 \pm 0.18$ & $35.00 \pm 0.31$ \\
\hline & & 400 & $8.04 \pm 0.06$ & $45.04 \pm 0.31$ & $22.18 \pm 0.22$ & $35.60 \pm 0.40$ \\
\hline & \multirow{3}{*}{ Methanol } & 100 & $8.52 \pm 0.15$ & $45.66 \pm 0.22$ & $21.28 \pm 0.21$ & $37.20 \pm 0.66$ \\
\hline & & 200 & $7.92 \pm 0.15$ & $46.82 \pm 0.34$ & $21.31 \pm 0.14$ & $37.60 \pm 0.50$ \\
\hline & & 400 & $7.38 \pm 0.18$ & $48.66 \pm 0.20$ & $22.34 \pm 0.27$ & $39.20 \pm 0.37$ \\
\hline Positive control & Diminazine aceturate & 28 & $5.52 \pm 0.07$ & $50.64 \pm 0.15$ & $22.61 \pm 0.17$ & $44.00 \pm 0.63$ \\
\hline Negative control & $2 \%$ Tween 80 & $2 \mathrm{ml} / 100 \mathrm{gm}$ & $8.82 \pm 0.12$ & $40.58 \pm 0.27$ & $19.09 \pm 0.34$ & $25.40 \pm 0.43$ \\
\hline
\end{tabular}

Table 7: Comparison of the effect of aqueous and methanol extract of Clutia abyssinica on parasitaemia, packed cell volume, body weight, and survival time of Trypanosoma congolense infected mice at the end of the experimental study.

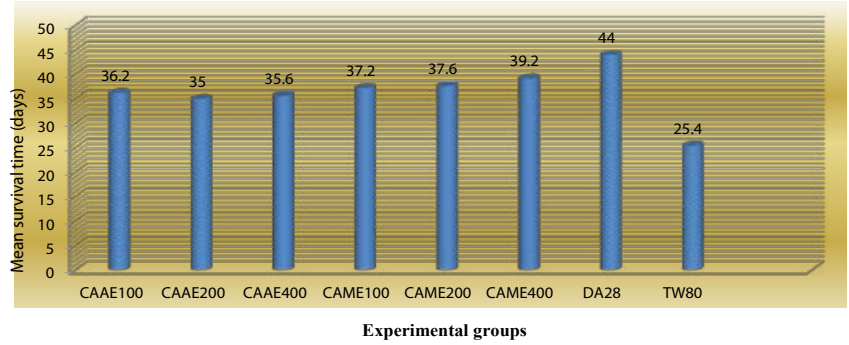

Figure 4: Survivality of Trypanosoma congolense infected mice treated with aqueous and methanol crude extracts of leaves of Clutia abyssinica and Verbascum sinaiticum

it was shown that the ethanolic leaf, stem and root extracts of $C$. abyssinica showed moderate antiviral activity against polio virus and Coxsackie virus [43], while the leaf extracts exhibited anti-HIV-1 activity [44]. Although we do not yet know the mechanism by which the extract exerts this remarkable trypanostatic effect, our speculation is that the extract may be interfering with cell cycle progression in the parasite, possibly causing cell cycle arrest and thereby halting cell proliferation, which is a similar mechanism for currently available antitrypanosomal agents. It is also possible that the extract might be exerting its trypanostatic effect through the modulation of the animal's immune system, which in turn enables the animal to withstand the ravaging parasites for a long time. It may well be the interplay of both effects that resulted in the observed tremendous trypanostatic effect.

In addition, the findings of this study had shown that the plant extracts did not completely eliminate parasites from the blood stream of infected mice, but only reduced the level of parasitaemia. Several researchers made similar observations on reduction in parasitaemia $[8,9,45]$ and concluded that high parasite load could mask the efficacy of crude extract [46]. Also, the reduced efficacy of the crude extracts in clearing trypanosomes from blood circulation could be due to enzymatic inactivation of active compounds and impaired absorption from the site of administration [47]. In addition, failing to reach target organs in sufficient concentration and duration to effect a cure; short half-life of the constituents making them unable to stay long enough to exert pronounced effect on the parasites [48] could also be attributed to the failure of the extracts to clear the blood of infected mice from trypanosomes.

In the group of mice treated with diminazine aceturate, there was no parasite development from day 2 to 10 . Although relapse occurred in all mice, approximately on days 12-14 of treatment. Similar observations were made by [9,49-52]. The relapse of parasitaemia might be due to trypanocidal drug resistance by trypanosomes or the ability of $T$. congolense to sequester in small vessels and capillaries of the heart, skeletal and other tissues [53-55]. The study on packed cell volume
(PCV) gave results that were fairly consistent with the observations made on parasitaemia (Figure 2). Infection caused significant drop in PCV in the negative control groups approximately by day 25 post infection (14th day of treatment) with mean value being below the reference values $(42-52 \%)$.

The low PCV value in the infected groups may be due to acute hemolysis and is a result of the growing infection. In addition infection with trypanosomes results in increased susceptibility of red blood cell membrane to oxidative damage. Reactive oxygen species generated by trypanosomes can also attack red blood cells' membranes, induce oxidation and subsequently hemolysis. This phenomenon subjects RBC to massive erythrophagocytosis by an expanded and active mononuclear phagocytic system (MPS) of the host resulting in anemia [56]. Thus, scavenging the trypanosome associated free radicals may ameliorate anemia.

The effect of extracts in ameliolating anemia is possibly by reducing the parasite load, neutralizing the toxic metabolites produced by trypanosomes or scavenging the trypanosome associated free radicals which could be attributed to the secondary metabolites present in the extracts [46,59-63].

The infected mice treated with the diminazine aceturate showed significant improvement in PCV. This is because the drug was able to eliminate parasites from the blood to levels detectable by microscopy on days $2-10$. This is in harmony with previous reports $[59,60]$.

The trypano suppresive effect of the extracts against trypanosome infection can further be inferred from the weight status of the treated animals. At day 14 post-treatment, animals that received $400 \mathrm{mg} / \mathrm{kg}$ dose of the aqueous and methanol extracts of $C$. abyssinica gained weight by $0.77 \%$ and $1.36 \%$, respectively (Tables 3 and 4$)$ at $(p<0.001)$ as compared to the negative control groups. This shows that as a result of reduction in parasitaemia and prevention of drop in PCV by the extracts physical status of the treated mice improved. They were therefore more able to resist weight loss that is usually associated with trypanosomosis. Similar observations have been made by other researchers [46,59,60-63].

Based on our findings, animals in the negative control group lost $11.03 \%$ of their body weight which might be due to the significant drop in PCV associated with high level of parasitaemia in this group. The majority of trials provide evidence of the negative effect of trypanosomosis on body weight. During the high levels of parasitaemia the appetite is decreased and the animal losses condition as a result there is wasting. There is consumption of the fat reserves but there are also severe degenerative changes of the muscle cells and other tissue cells, and there is an increased breakdown of protein in muscles and elsewhere, leading to atrophic degeneration. The decreased supply of oxygen because of the anemia is also an important factor [64-66]. 
Citation: Mergia E, Shibeshi W, Terefe G, Teklehaymanot T (2014) Evaluation of In vivo Antitrypanosomal Activity of Aqueous and Methanol Leaf Extracts of Clutia abyssinica (Euphorbiaceae) against Trypanosoma congolense Field Isolate. Nat Prod Chem Res $2: 138$. doi:10.4172/23296836.1000138

Page 7 of 8

\section{Conclusion}

This study gave indications of in vivo antitrypanosomal activity of methanol crude leaf extracts of $C$. abyssinica against T. congolence field isolate. The work demonstrated good safety margin of the crude extracts in mice suggesting their ethnopharmacological usefulness. The aqueous extract exhibited lower in vivo antitrypanosomal activity, while the methanol extracts have shown higher in vivo activity at higher doses. However, both extracts were not effective enough to eradicate the parasites completely. The study revealed that methanol leaf extract of $C$. abyssinica has promising effect by reducing pre-treatment parasitemia by $3.91 \%(7.38 \pm 0.18)$, increasing PCV by $1.12 \%(48.66 \pm$ $0.20)$, increasing pretreatment body weight by $1.36 \%(22.34 \pm 0.27)$ and prolonging survival time by $39.20 \pm 0.37$ days in T. congolense infected mice.

Generally, the current study established that leaves of C. abyssinica could have potential antitrypanosomal activity which can be considered as a potential source for the search of new drugs against Africal animal trypanosomosis.

\section{Acknowledgment}

We would like to thank staffs of the NTTICC for technical assistance during isolation of the test organism; Vice President for research and Technology transfer of Addis Ababa university (AAU) for partly funding the research under the framework of the thematic research project, Animal Health Improvement; and staffs of ALIPB for their cooperation and unreserved help during the laboratory work.

\section{References}

1. Getachew A (2005) Trypanosomosis in Ethiopia. J Biol Sci 4: 75-121.

2. Chanie M, Adula D, Bogale B (2013) Socio-Economic assessment of the impacts of trypanosomiasis on cattle in Girja district, Southern Oromia Region, Southern Ethiopia. Acta Parasitologica Globalis 4: 80-85.

3. Albadrani BA (2012) Clinical and hematological study of Trypanosoma bruce and Trypanosoma congolense in cattle in Mosul City, Iraq Res Opin Anim Vet Sci 2: $92-97$

4. Chitanga S, Marcotty T, Namangala B, Van den Bossche P, Van Den Abbeele $\mathrm{J}$, et al. (2011) High prevalence of drug resistance in animal trypanosomes without a history of drug exposure. PLoS Negl Trop Dis 5: e1454.

5. Amaechi N (2001) Toxicity of antiprotozoan drug, diminazene aceturate in rats Journal of Sustainable Agriculture and Environment 3: 365-370.

6. Hoet S, Opperdoes F, Brun R, Quetin-Leclercq J (2004) Natural products active against African trypanosomes: a step towards new drugs. Nat Prod Rep 21 353-364.

7. Samson W (2005) Studying herbal remedies. N Engl J Med 353: 337-339

8. Wurochekke AU, Nok AJ (2004) In vitro and in vivo antitrypanosomal activity of the leaf of Lawsonia inermis against Trypanosoma brucei brucei infection in mice. J Medical Sci 4: 236-239.

9. Ibrahim H, Ogbadoyi E, Adamu K, Bello M, Yemisi I (2012) Evaluation of antitrypanosomal activity of ethyl acetate extract of adansonia digitata seed extract in T. b. brucei infected albino mice. Int J Drug Res Tech 2: 454-460.

10. Shuaibu MN, Wuyep PT, Yanagi T, Hirayama K, Ichinose A, et al. (2008) Trypanocidal activity of extracts and compounds from the stem bark of Anogeissus leiocarpus and Terminalia avicennoides. Parasitol Res 102: $697-$ 703.

11. Edwards S, Tadesse M, Hedberg I (1995) Flora of Ethiopia and Erteria Canellacea to Euphorbiacea, The National Herbarium, Addis Ababa and Uppsala University 2: 286-290.

12. Pascaline J, Charles M, Lukhoba C, George O (2011) Phytochemical constituents of some medicinal plants used by the Nandis of South Nand district, Kenya. Journal of Animal and Plant Sciences 9: 1201- 1210.

13. Runyoro DK, Ngassapa OD, Matee MI, Joseph CC, Moshi MJ (2006) Medicinal plants used by Tanzanian traditional healers in the management of Candida infections. J Ethnopharmacol 106: 158-165.

14. Matu EN (2008) Clutia abyssinica Jaub. \& Spach. In: Schmelzer, G.H. \& Gurib-
Fakim, A. (Editors). Prota 11(1): Medicinal plants/Plantes médicinales PROTA Wageningen, Netherlands.

15. Fowler DG (2006) Traditional Fever remedies: a list of Zambian plants.

16. Njoroge GN, Bussmann RW (2006) Traditional management of ear, nose and throat (ENT) diseases in Central Kenya. J Ethnobiol Ethnomed 2: 54.

17. Yineger H, Kelbessa E, Bekele T, Lulekal E (2007) Ethnoveterinary medicinal plants at Bale Mountains National Park, Ethiopia. J Ethnopharmacol 112: 55 70 .

18. Fullas $F(2010)$ Ethiopian medicinal plants in veterinary health care. Ethiopian e-journal for research and innovation 2: 48-58.

19. Woo PT (1970) The haematocrit centrifuge technique for the diagnosis of African trypanosomiasis. Acta Trop 27: 384-386.

20. Murray M, Murray PK, McIntyre WI (1977) An improved parasitological technique for the diagnosis of African trypanosomiasis. Trans R Soc Trop Med Hyg 71: 325-326.

21. Uilenberg G (1998) Field guide for diagnosis, treatment and prevention of African animal trypansomosis. Food and agriculture organization of the United Nations Publications, Rome.

22. Herbert WJ, Lumsden WH (1976) Trypanosoma brucei: a rapid "matching" method for estimating the host's parasitemia. Exp Parasitol 40: 427-431.

23. Fukui Y, Ema M, Fujiwara M, Higuchi H, Inouye M, et al. (2004) Comments from the Behavioral Teratology Committee of the Japanese Teratology Society on OECD guideline for the testing of chemicals, proposal for a new guideline 426, developmental neurotoxicity study, draft document (September 2003). Congenit Anom (Kyoto) 44: 172-177.

24. Briggs MH (1970) Advances in Steroid Biochemistry and Pharmacology. New York, USA, Academic Press, 24.

25. Dermarderosian A, Liberti LE (1988) Natural products medicine: A scientific guide to foods, drugs and cosmetics, 1st Ed., Philadelphia, USA: Geo. F. Stickley Co., 46-66.

26. Evans W (1996) Trease and Evans' Pharmacognosy, 14th Edition. W.B. Saunders Ltd.105-766.

27. Rafauf $R$ (1970) Handbook of alkaloids and alkaloid containing plants. Wiley New York USA: 2nd Edition, Academic Press.

28. Sofowora A (1996) Medicinal plants and traditional medicine in Africa. J Altern Complement Med 2: 365-372.

29. Tyler VE, Brady LR, Robbers JE (1988) Pharmacognosy, 9th Edition. Philadelphia, USA: Lea and Febiger.

30. Lorke D (1983) A new approach to practical acute toxicity testing. Arch Toxico 54: 275-287.

31. OIE, Institute for International Cooperation in Animal Biologics (2013) Terrestrial manual trypanosomiasis: Tsetse-transmitted

32. Wintrobe MM, Landsberg JW (1970) A standardized technique for the blood sedimentation tset. American Journal of medical science 189: 102-104.

33. Wernery U, Zachariah R, Mumford JA, Luckins T (2001) Preliminary evaluation of diagnostic tests using horses experimentally infected with trypanosoma evansi. Vet J 161: 287-300.

34. Yabu Y, Yoshida A, Suzuki T, Nihei C, Kawai K, et al. (2003) The efficacy of ascofuranone in a consecutive treatment on Trypanosoma brucei brucei in mice. Parasitol Int 52: 155-164.

35. Nok AJ (2002) Azaanthraquinone inhibits respiration and in vitro growth of long slender bloodstream forms of Trypanosoma congolense. Cell Biochem Funct 20: 205-212.

36. Harborne JB, Williams CA (2000) Advances in flavonoid research since 1992 Phytochemistry 55: 481-504.

37. Taylor $L$ (2000) Plant based drugs and medicine. Rain tree Nutrition Inc., 1-5.

38. Nibret E, Wink M (2010) Volatile components of four Ethiopian Artemisia species extracts and their in vitro antitrypanosomal and cytotoxic activities. Phytomedicine 17: 369-374.

39. Nibret E, Petros B, Mekonnen Y (2007) Evaluation of the efficacy of traditionally used medicinal Plants extracts against $T$. congolense in vivo in mice. Ethiop Vet J 11:151-162. 
Citation: Mergia E, Shibeshi W, Terefe G, Teklehaymanot T (2014) Evaluation of In vivo Antitrypanosomal Activity of Aqueous and Methanol Leaf Extracts of Clutia abyssinica (Euphorbiaceae) against Trypanosoma congolense Field Isolate. Nat Prod Chem Res $2: 138$. doi:10.4172/23296836.1000138

Page 8 of 8

40. Saeidnia S, Gohari AR, Uchiyama N, Ito M, Honda G, et al. (2004) Two new monoterpene glycosides and trypanocidal terpenoids from Dracocephalum kotschyi. Chem Pharm Bull (Tokyo) 52: 1249-1250.

41. Abd El Hady FK, Hegazi AG (2002) Egyptian propolis: 2. Chemical composition, antiviral and antimicrobial activities of East Nile Delta propolis. Z Naturforsch C 57: 386-394.

42. Pelttari E, Matikainen J, Elo H (2002) Antimicrobial activity of the marine alkaloids haminol and pulo'upone and related compounds. Z Naturforsch C 57: $548-552$

43. Colegate SM, Molyneux RJ (1993) Bioactive Natural Products Detection, Isolation, and Structural Determination. CRS press Inc. 1-423.

44. Cos P, Hermans N, De Bruyne T, Apers S, Sindambiwe JB, et al. (2002) Antiviral activity of Rwandan medicinal plants against human immunodeficiency virus type-1 (HIV-1). Phytomedicine 9: 62-68.

45. Ogbadoyi E, Adamu Y, Omotosho R (2011) Preliminary studies of the antitrypanosomal activity of Garcinia kola nut extract in mice infected with $\mathrm{T}$. b. brucei. Journal of Medicine and Medical Sciences 2: 628-631.

46. Ekanem JT, Kolawole OM, Abbah OC (2008) Some biochemical and haematological effects of black seed (Nigella sativa) oil on Trypanosoma brucei infected rats. Afr J Biochem Res 2: 79-85.

47. Mann A, Egwim EC, Banji B, Abdukadir N, Gbate M, et al. (2009) Efficacy of Dissotis rotundifolia on Trypanosoma brucei brucei infection in rats. Afr $J$ Biochem Res 3: 5-8.

48. Williams S, Saha L, Singha UK, Chaudhuri M (2008) Trypanosoma brucei: differential requirement of membrane potential for import of proteins into mitochondria in two developmental stages. Exp Parasitol 118: 420-433.

49. Afewerk Y, Clausen PH, Abebe G, Tilahun G, Mehlitz D (2000) Multiple-drug resistant Trypanosoma congolense populations in village cattle of Metekel district, north-west Ethiopia. Acta Trop 76: 231-238

50. Assefa E, Abebe G (2001) Drug-resistant Trypanosoma congolense in naturally infected donkeys in north Omo Zone, southern Ethiopia. Vet Parasitol 99: 261 271.

51. Delespaux V, Geysen D, Van den Bossche P, Geerts S (2008) Molecular tools for the rapid detection of drug resistance in animal trypanosomes. Trends Parasitol 24: 236-242.

52. Miruk A, Hagos A, Yacob HT, Asnake F, Basu AK (2008) Prevalence of bovine trypanosomosis and trypanocidal drug sensitivity studies on Trypanosoma congolense in Wolyta and Dawero zones of southern Ethiopia. Vet Parasitol 152: $141-147$.

53. Losos GJ, Iked BO (1973) Review of the pathology of domestic and laboratory animal caused by T. congolence, T. vivax, T. brucei, T. rhodesiense and T. gambiense. Vet Pathol 9:1-79.

54. Maxie MG, Losos GJ (1977) Release of Trypanosoma congolense from microcirculation of cattle by berenil. Vet Parasitol 3: 277-281.

55. Mbaya AW, Nwosu CO, Onyeyili PA (2007) Toxicity and anti-trypanosomal effects of ethanolic extract of Butyrospermum paradoxum (Sapotaceae) stem bark in rats infected with Trypanosoma brucei and Trypanosoma congolense. J Ethnopharmacol 111: 526-530.

56. Albert M, Hussein K (2012) The Mechanisms of anemia in trypanosomiasis: A Review, Anemia, Dr. Donald Silverberg (Edition).

57. Mpiana PT, Tshibangu DS, Shetonde OM, Ngbolua KN (2007) In vitro antidrepanocytary actvity (anti-sickle cell anemia) of some congolese plants. Phytomedicine 14: 192-195.

58. Ogoti P, Magiri E, Auma J, Magoma G, Imbuga M, et al. (2009) Evaluation of In vivo antitrypanosomal activity of selected medicinal plant extracts. $\mathrm{J}$ of Med Plant Research 3: 849-854

59. Inabo HI, Fathuddin MM (2011) In vivo antitrypanosomal potentials of ethy acetate leaf extracts of Punica granatum against T. b. brucei. Advances in Agricultural biotechnology 1: 82-86.

60. Umar IA, Ibrahim MA, Fari NA, Isah S, Balogun DA (2010) In vitro and in vivo antitrypanosoma evansi activities of extracts from different parts of Khaya senegalensis. Journal of Cell and Animal Biology 4: 91-95.

61. Abubakar A, Iliyasu B, Yusuf AB, Igweh AC, Onyekwelu NA, et al. (2005) Antitrypanosomal and haematological effects of selected Nigerian medicinal plants in Wistar rats. Biokemistri 17: 95-99.

62. Adamu M, Nwosu CO, Igbokwe $1 O$ (2008) Toxicity and Phytochemical Constituents of aqueous Extract of Ocimum gratissimum Leaf. Nig Vet J 29: 48-57.

63. Alli LA, Okochi VI, Adesoken AA (2011) Antitrypanosomal activity and hematological effects of aqueous extract of leaves of Morinda Lucida on Trypanosoma brucie brucie infected rats. Asian J pharm hea Sci 1: 111-115.

64. Holmes PH, Katunguka-Rwakishaya E, Bennison JJ, Wassink GJ, Parkins JJ (2000) Impact of nutrition on the pathophysiology of bovine trypanosomiasis. Parasitology 120 Suppl: S73-85.

65. Yusuf AB, Umar IA, Musa UB, Nok AJ (2012) Screening of Vernonia amygdalina and Hymenocardia acida extracts and 1,3-diaminopropane for their antitrypanosomal activities: in vitro model. J Med Plants Res 6: 3573-3578.

66. Tatli, Zeliha, Akdemír (2004) Chemical Constituents of Verbascum L. Species FABAD. J Pharm Sci 29: 93-107. 